surprising observation was that in 11 of 14 familial tumours there were errors in DNA replication not only in the dinucleotide repeat marker on chromosome 2 but throughout the tumour genome, and replication errors also affected trinucleotide repeats, indicating widespread genetic instability. Multiple replication errors have also been found in $13 \%$ of sporadic tumours. ${ }^{1213}$ The tumours with errors were found to have some of the characteristics of familial tumours-they were more frequently right sided and diploid and had a lower frequency of loss of heterozygosity despite there being no characteristic family history. These results suggest that up to $15 \%$ of apparently sporadic tumours may be associated with genetic instability.

Familial colon cancer associated with the gene mapped to chromosome 2 may be one of most common forms of heritable disease in man. It seems to cause errors of DNA replication in tumours. Identification and characterisation of the gene should greatly facilitate surveillance programmes for colon cancer (and associated cancers) in affected individuals and may ultimately permit population screening. Even before the gene is isolated, however, more effort should be made to recognise patients with familial colon cancer so that they and their relatives are managed appropriately. This should probably include screening those at risk from the age of 25 by colonoscopy every three to five years and, in women, by pelvic ultrasonography. Those who develop colorectal cancer should be treated by subtotal colectomy-these patients have a high incidence of metachronous colonic tumours. ${ }^{14}$

HJW THOMAS

St Mary's Hospital,

Senior registrar in gastroenterology

London W2 $1 \mathrm{NY}$

1 Peltomaki P, Aaltonen L, Sistonen P, Pylkkanen L, Mecklin JP, Jarvinen H, et al. Genetic mapping of a locus predisposing to human colorectal cancer. Science 1993;260:810-2.

2 Aaltonen LA, Peltomaki P, Leach FS, Sistonen P, Pylkkanen L, Mecklin JP, et al. Clues to the pathogenesis of familial colorectal cancer. Science 1993;260:812-6.

3 Bodmer WF, Bailey CJ, Bodmer J, Bussey HJR, Ellis A, Gorman P, et al. Localization of the gene for familial adenomatous polyposis on chromosome 5 . Nature 1987;328:614-6.

4 Leppert M, Dodds M, Scambler P, O'Connel P, Nakamura Y, Stauffer D, et al. The gene for familial polyposis coli maps to the long arm of chromosome 5. Science 1987;238:1411-3.

5 Nakamura $Y$, Lathrop $M$, Leppert $M$, Dobbs $M$, Wasmuth J, Wolff $E$, et al. Localization of the genetic defect in familial adenomatous polyposis within a small region of chromosome 5. Am $\mathscr{f}$ Hem 1988 ;3:638-44.

6 Varesco L, Thomas HJW, Cottrell S, Murday V, Fennell SJ, Williams S, et al. CpG island clones from a deletion encompassing the gene for adenomatous polyposis coli. Proc Natl Acad Sci USA 1989;86:10118-22.

7 Kinzler KW, Nilbert MC, Su LK, Vogelstein B, Bryan TM, Levy DB, et al. Identification of FAP locus genes from chromosome 5q21. Science 1991;253:661-5.

8 Groden J, Thliveris A, Samowitz W, Carlson M, Gelbert L, Albertsen H, et al. Identification and characterization of the familial adenomatous polyposis gene. Cell 1991;66:589-600.

9 Vasen HFA, Mecklin JP, Meera Khan P, Lynch HT. The international collaborative group on hereditary non-polyposis colorectal cancer. Dis Colon Rect 1991;34:424-5.

10 Jass JR, Stewart SM. Evolurion of hereditary non-polyposis colorectal cancer. Gut 1992;33:783-6.

11 Fearon ER, Vogelstein B. A genetic model for colorectal tumorigenesis. Cell 1990;61:759-67.

12 Thibodeau SN, Bren G, Schaid D. Microsatellite instability in cancer of the proximal colon. Science 1993;260:816-9.

13 Ionov Y, Peinado MA, Malkhosyan S, Shibata D, Perucho M. Ubiquitous somatic mutations in simple repeat sequences reveal a new mechanism for colonic carcinogenesis. Nature 1993;363: 558-61.

14 Lynch HT, Smyrk TC, Watson P, Lanspa SJ, Lynch JF, Lynch PM, et al. Genetics, natural history, tumour spectrum, and pathology of hereditary nonpolyposis colorectal cancer: an updated review. Gastroenterology 1993;104:1535-49.

\title{
Aspirin and colorectal cancer
}

\section{Seems to reduce risk}

Aspirin is used to relieve pain, reduce fever, treat arthritis, and prevent heart attacks and stroke. Will it also prevent colorectal cancer?

Four recent epidemiological studies have examined the association between the use of non-steroidal anti-inflammatory drugs (primary aspirin) and colorectal cancer, ${ }^{1-6}$ and in this week's journal, Logan and colleagues describe a casecontrol study of use of aspirin and colorectal adenomas ( $p$ 285). ${ }^{7}$ Their findings increase support for the regular use of aspirin reducing the risk of colorectal cancer. Subjects were recruited from participants performing faecal occult blood tests in a randomised trial of screening for colorectal cancer in Nottingham. Patients whose adenomatous colorectal polyps were diagnosed after a positive faecal occult blood test result were compared with two control groups: those with positive faecal occult blood test results but without adenomas or carcinomas and those who tested negative for faecal occult blood. The relative risk of developing colorectal adenomas for any use of non-steroidal anti-inflammatory drugs was 0.49 compared with the positive controls and 0.66 compared with the negative controls.

Two control groups yielding similar results add credence to the findings. But if controls are generally more health conscious than index patients (their intake of more prescribed drugs suggests that they might see their doctors more frequently and be the "worried well"), the association of use of aspirin with other attributes of a healthy lifestyle might result in the observed lowered risk of colorectal cancer. Also, past treatment for ulcers or indigestion (contraindications to non-steroidal anti-inflammatory drugs) increased the risk of adenomatous polyps by $30-40 \%$ and might explain some of the protection observed among aspirin users. The possibility of selection bias or residual confounding cannot therefore be completely discounted.

All epidemiological studies associating use of aspirin and colorectal cancer or adenomas lack random assignment of subjects to aspirin or placebo. In such studies, casual relations between exposure and disease are identified by consistency, the strength of the association, a dose-response effect, the change in risk after exposure has stopped, and biological plausibility.

The reduction in the risk of colorectal cancer and adenoma among aspirin users occurred in different geographical regions, including Australia, ${ }^{1}$ the United States, ${ }^{23}$ and England. ${ }^{7}$ The association was evident in retrospective casecontrol $^{127}$ and prospective cohort ${ }^{3}$ studies. Furthermore, deaths from colonic cancer ${ }^{3}$ and the incidence of colorectal cancer ${ }^{12}$ and adenomas fell. ${ }^{7}$ Thus the consistency criterion is met. All but one.study, which found no protective effect of aspirin on the incidence of or mortality from colorectal cancer, ${ }^{4-6}$ have estimated that use of aspirin about halves the risk of colonic cancers and adenomas, indicating a strong association.

Little information is available regarding a dose-response effect: only Thun et al reported a significant trend of decreasing risk with increasing frequency of use of aspirin. ${ }^{3}$ Logan and colleagues reported that all categories of usefrom 1-2 to 13 times a year-similarly reduced risk. ${ }^{7}$ Little is known about how risk changes after exposure has stopped: Rosenberg et al reported no protective effect in people who had used aspirin in the past regardless of the duration of use. ${ }^{2}$

How non-steroidal anti-inflammatory drugs inhibit colorectal cancer is not well understood. In animal models, cell cultures, and humans these drugs reduce the concentrations 
of prostaglandins by inhibiting cyclo-oxygenase, the enzyme at the first step in the biosynthesis of prostaglandin from arachidonic acid. ${ }^{8}$ Interference with prostaglandin synthesis may prevent cancer by inhibiting cell proliferation, boosting the immune system, or blocking synthesis of tumour promoters. By inhibiting prostaglandin synthesis, non-steroidal anti-inflammatory drugs may reduce ornithine decarboxylase activity and thus slow tumour growth and metabolic activity. ${ }^{8}$ In a few studies, however, aspirin and indomethacin have stimulated ornithine decarboxylase activity and cell proliferation, including proliferation in the colonic mucosa. ${ }^{9}$

Alternatively, by blocking production of immunologically inhibiting prostaglandins by suppressor cells, including that in mitogen stimulated cultures of cells from patients with colorectal cancer, ${ }^{10}$ non-steroidal anti-inflammatory drugs may activate immune reactions against tumours. These drugs may also inhibit the synthesis of tumour promoters by blocking the prostaglandin dependent co-oxidation of many chemicals to form carcinogens. ${ }^{11}$

Although these epidemiological studies are generally consistent and show a strong and biologically plausible relation between use of aspirin and colorectal cancer, they are inconclusive regarding a dose-response effect and a change in risk after exposure has stopped. Further studies, in different populations and with different methods, are required to exclude non-causal explanations and sort out conflicting results. A clinical trial randomising patients to aspirin or placebo would be the definitive test of aspirin's effectiveness in preventing colorectal cancer. Previous trials of aspirin have lacked the large numbers and follow up necessary to evaluate any preventive effect on colorectal cancer. ${ }^{12}{ }^{13} \mathrm{~A}$ trial to test whether aspirin can prevent the recurrence of colorectal adenomatous polyps or cause sporadic adenomas to regress is feasible, requiring relatively small numbers and follow up of less than five years.

Even if aspirin unambiguously prevented colorectal cancer, other risks should be considered before regular use is begun. Aspirin is nephrotoxic and can produce renal papillary necrosis and renal failure. ${ }^{14}$ The development of tumours of the urinary tract is another serious long term complication..$^{14}$ Although regular use of aspirin benefits patients with established coronary heart disease, ${ }^{16}$ its effects on the primary prevention of stroke and cardiovascular death remain inconclusive. ${ }^{41213}$

\section{ANNLIA PAGANINI-HILI}

Professor

Department of Preventive Medicine,

University of Southern California School of Medicine,

Los Angeles, CA 90031

1 Kune GA, Kune S, Watson LF. Colorectal cancer risk, chronic illnesses, operations and medications: case control results from the Melbourne colorectal cancer study. Cancer $R$ medications: case

2 Rosenberg L, Palmer JR, Zauber AG, Warshauer ME, Stolley PD, Shapiro S. A hypothesis: nonsteroidal anti-inflammatory drugs reduce the incidence of large-bowel cancer. $\mathcal{I}$ Natl Cancer Inst 1991;83:355-8.

Thun MJ, Namboodiri MM, Heath CW Jr. Aspirin use and reduced risk of fatal colon cancer. N Engl F Med 1991;325:1593-6.

4 Paganini-Hill A, Chao A, Ross RK, Henderson BE. Aspirin use and chronic diseases: a cohor study of the elderly. $B M F 1989 ; 299: 1247-50$.

5 Paganini-Hill A, Hsu G, Ross RK, Henderson BE. Aspirin use and incidence of large-bowel cancer

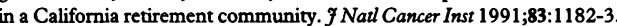

6 Paganini-Hill A, Hsu G, Ross RK, Henderson BE. Aspirin and reduced risk of fatal colon cancer. N Engl f Med 1992;326:1290.

7 Logan RFA, Little J, Hawtin PG, Hardcastle JD. Effect of aspirin and non-steroidal antiinflammatory drugs on colorectal adenomas: a case-control study of subjects participating in the inflammatory drugs on colorectal adenomas: a case-control study of subjects

8 Verma AK, Ashendel CL, Boutwell RK. Inhibition by prostaglandin synthesis inhibitors of the induction of epidermal ornithine decarboxylase activity, the accumulation of prostaglandins, and umor promotion caused by 12-O-tetradecanoylphorbol-13 acetate. Cancer Res 1980;40:308-15.

9 DeRubertis FR, Craven PA, Saito R. 16,16-Dimethyl prostaglandin $E_{2}$ suppresses the increases in the proliferative activity of rat colonic epithelium induced by indomethacin and aspirin Gastroenterology 1985;89:1054-63.

10 Han T, Nemoto T, Ledesma EJ, Bruno S. Enhancement of T lymphocyte proliferative response to mitogens by indomethacin in breast and colorectal cancer patients. Int $f$ Immunopharmacol 1983;5:11-5.

11 Narisawa T, Hermanek P, Habs M, Schmahl D. Reduction of carcinogenicity of N-nitrosomethylurea by indomethacin and failure of resuming effect of prostaglandin $\mathrm{E}_{2}\left(\mathrm{PGE}_{2}\right)$ against indomethacin. 7 Cancer Res Clin Oncol 1984;108:239-42.

12 Steering Committee of the Physicians' Health Study Research Group. Final report on the aspirin component of the ongoing physicians' health study. $N$ Engl F Med 1989;321:129-35.

13 Peto R, Gray R, Collins R, Wheatley K, Hennekens C, Jamrozik K, et al. Randomised trial of the effects of prophylactic daily aspirin among male British doctors. $B M F$ 1988;296:313-6.

14 Prescott LF. Analgesic nephropathy: a reassessment of the role of phenacetin and other analgesics. Drugs 1982;23:75-149.

15 Paganini-Hill A, Ross RK, Henderson BE. Epidemiology of renal cancer. In: Skinner DG, Lieskovsky G, eds. Diagnosis and management of genitourinary cancer. Philadelphia: W B Saunders, 1988:32-9.

6 Antiplatelet Trialists' Collaboration. Secondary prevention of vascular disease by prolonged antiplatelet treatment. $B M \mathcal{F}$ 1988;296:320-31.

\section{The gene for von Hippel-Lindau disease}

\section{Will improve diagnosis}

Von Hippel-Lindau disease is a dominantly inherited cancer syndrome with potentially devastating effects. Its most common complications are retinal angiomatosis, central nervous system haemangioblastomas, renal cell carcinoma, phaeochromocytoma, and pancreatic tumours. ${ }^{1}$ At least one in 36000 people have the disease, and for every case there will be another four or five relatives with a greater than $25 \%$ chance of carrying the gene. ${ }^{2}$ Recognising the disease is important because regular screening of affected patients and relatives at risk of the disease reduces morbidity and mortality. ${ }^{3}$

With no clues to the underlying biochemical defect, considerable effort has been expended in isolating the gene for the disease. In 1988 it was mapped to the short arm of chromosome $3,{ }^{4}$ and further studies narrowed down the target area containing the gene. Now an international collaboration between groups at the American National Cancer Institute and the University of Cambridge has isolated the gene. ${ }^{5}$

What is the clinical and biological significance of this discovery? Firstly, the development of direct molecular genetic diagnosis of von Hippel-Lindau disease will improve presymptomatic diagnosis within affected families. Relatives who are shown not to have inherited the mutation can be reassured and spared a lifetime of repeated investigation. This will increase the cost effectiveness of screening for the disease. In addition, direct molecular genetic diagnosis will enable individuals with possible disease (for example, those with familial or early onset renal cell carcinoma or apparently isolated cases of retinal angiomatosis or cerebellar haemangioblastoma) to be tested for the gene mutations.

The abnormal gene in von Hippel-Lindau acts as a tumour suppressor gene, but the precise biochemical function of the gene product has not yet been elucidated. ${ }^{5}$ Much interest has been focused on isolating familial cancer genes because these genes are frequently implicated in the pathogenesis of common sporadic cancers. The finding of the gene mutations of von Hippel-Lindau disease in non-familial renal cell carcinomas has again validated this concept. Thus the isolation of the gene for von Hippel-Lindau disease is a landmark for research into inherited cancer predisposition and into the molecular pathogenesis of renal cell carcinoma, which accounts for $2-3 \%$ of all human cancers. The challenge 